\title{
Genetic divergence of tomato subsamples
}

\author{
André Pugnal Mattedi ${ }^{1}$, Marcelo de Almeida Guimarães ${ }^{2}$, Carlos Nick ${ }^{3}$, Derly José Henriques da Silva ${ }^{4}$, \\ Mário Puiatti ${ }^{5}$ Pedro Crescêncio Souza Carneiro 6
}

\begin{abstract}
Understanding the genetic variability of a species is crucial for the progress of a genetic breeding program and requires characterization and evaluation of germplasm. This study aimed to characterize and evaluate 101 tomato subsamples of the Salad group (fresh market) and two commercial controls, one of the Salad group (cv. Fanny) and another of the Santa Cruz group (cv. Santa Clara). Four experiments were conducted in a randomized block design with three replications and five plants per plot. The joint analysis of variance was performed and characteristics with significant complex interaction between control and experiment were excluded. Subsequently, the multicollinearity diagnostic test was carried out and characteristics that contributed to severe multicollinearity were excluded. The relative importance of each characteristics for genetic divergence was calculated by the Singh's method (Singh, 1981), and the less important ones were excluded according to Garcia (1998). Results showed large genetic divergence among the subsamples for morphological, agronomic and organoleptic characteristics, indicating potential for genetic improvement. The characteristics total soluble solids, mean number of good fruits per plant, endocarp thickness, mean mass of marketable fruit per plant, total acidity, mean number of unmarketable fruit per plant, internode diameter, internode length, main stem thickness and leaf width contributed little to the genetic divergence between the subsamples and may be excluded in future studies.
\end{abstract}

Key words: Solanum lycopersicum, characterization, evaluation, genetic variability.

\section{RESUMO}

\section{Divergência genética de subamostras de tomateiro}

Para o avanço de um programa de melhoramento genético é fundamental o conhecimento da variabilidade genética existente na espécie, o que demanda estudos de caracterização e avaliação do germoplasma disponível. Objetivou-se neste estudo a caracterização e avaliação de 101 subamostras de tomateiro do grupo Salada e duas testemunhas comerciais, uma do grupo Salada (cv. Fanny) e outra do grupo Santa Cruz (cv. Santa Clara). Foram realizados quatro experimentos no delineamento em blocos casualizados, com três repetições e cinco plantas por parcelas. Foram realizadas análises de variância conjunta e descartadas as características com interação significativa do tipo complexa entre testemunha e experimento. Posteriormente, foi realizado o diagnóstico de multicolinearidade e descartadas as

Received: 21/11/2012; Approved: 29/11/2013.

Agronomist Engineer, Master of Science. Departamento de Fitotecnia, Universidade Federal de Viçosa, Campus Viçosa, Avenida Peter Henry Rolfs, s/n, 36570-000, Viçosa, Minas Gerais, Brasil. andremattedi@gmail.com

${ }^{2}$ Agronomist Engineer, Doctor of Science. Departamento de Fitotecnia, Universidade Federal do Ceará, Campus Pici, Avenida Mister Hull, 2977, Bloco 805, 60356-001, Fortaleza, Ceará, Brasil. mguimara@ufc.br (corresponding author).

${ }^{3}$ Agronomist Engineer, Doctor of Science. Departamento de Fitotecnia, Universidade Federal de Viçosa, Campus Viçosa, Avenida Peter Henry Rolfs, s/n, 36570-000, Viçosa, Minas Gerais, Brasil. carlos.nick@yahoo.com.br

${ }^{4}$ Agronomist Engineer, Doctor of Science. Departamento de Fitotecnia, Universidade Federal de Viçosa, Campus Viçosa, Avenida Peter Henry Rolfs, s/n, 36570-000, Viçosa, Minas Gerais, Brasil. derly@ufv.br

${ }_{5}^{5}$ Agronomist Engineer, Doctor of Science. Departamento de Fitotecnia, Universidade Federal de Viçosa, Campus Viçosa, Avenida Peter Henry Rolfs, s/n, 36570-000, Viçosa, Minas Gerais, Brasil. mpuiatti@ufv.br

${ }^{6}$ Agronomist Engineer, Doctor of Science. Departamento de Fitotecnia, Universidade Federal de Viçosa, Campus Viçosa, Avenida Peter Henry Rolfs, s/n, 36570-000, Viçosa, Minas Gerais, Brasil. carneiro@ufv.br 
características que contribuíam para níveis severos de multicolinearidade. A importância relativa de cada característica para divergência genética foi realizada pelo método de Singh (1981), e as de menor importância relativa foram descartadas conforme metodologia de Garcia (1998). Os resultados demonstram grande divergência genética entre as subamostras estudadas para as características morfológicas, agronômicas e organolépticas, indicando potencial para o melhoramento genético. As características sólidos solúveis totais, número médio de frutos bons por planta, espessura do endocarpo, massa média de frutos bons por planta, acidez total, número médio de frutos ruins por planta, diâmetro do entrenó, comprimento do entrenó, espessura do pecíolo principal e largura da folha pouco contribuíram para a divergência genética entre as subamostras, podendo ser descartadas em estudos futuros.

Palavras-chave: Solanum lycopersicum, caracterização, avaliação, variabilidade genética.

\section{INTRODUCTION}

Tomato breeding programs have aimed to increase the genetic diversity of their population base (Haussmann et al., 2004) in order to reach more productive cultivars (Marim et al., 2005; Guimarães et al., 2007) with better fruit quality (Guimarães et al., 2008) and other desirable cultivar traits.

The Vegetable Germplasm Bank of the Federal University of Viçosa (UFV - BGH) possesses over 850 recorded tomato subsamples, most of them of the salad group. Characterization of subsamples has been carried out for biotic and abiotic factors such as resistance to pests and diseases (Oliveira et al., 2009; Fiorini et al., 2010); assessment of production (Rodrigues et al., 2010); fruit quality (Caliman et al., 2005) agronomic characteristics (Castro et al., 2010).

The evaluation and characterization of subsamples result in large amount of information, including morphological, physiological, agronomic, biochemical, cytogenetic and molecular features. This information can be used in studies of genetic divergence to guide breeders in selecting potential crosses and strategies for genetic improvement of the species. These studies can also help determining the relative importance of characters for selecting those most informative for the characterization and evaluation of germplasm, knowledge on the relation between characters, and establishment of core collections that, with the smallest subsample number, can represent most of the genetic variability in the germplasm (Upadhyaya et al., 2006).

Studies on genetic divergence usually use multivariate techniques that, besides allowing the quantification of divergence among subsamples, also provide graphical representation of their relationship through dendrograms or scatter plots and identification of traits with the largest contribution to genetic divergence.
This study aimed to estimate the genetic divergence among 101 subsamples of tomato belonging to the Salad group and assess the relative importance of each of the characters analyzed.

\section{MATERIALS AND METHODS}

The experiments were conducted in the Vegetable Experimental Field of the Crop Science Department, Federal University of Viçosa (UFV), Viçosa - MG ( $20^{\circ} 45^{\prime} 14^{\prime \prime} \mathrm{S}$ and $42^{\circ} 52^{\prime} 53^{\prime \prime} \mathrm{W}, 648.74 \mathrm{~m}$ altitude). The regional climate is classified as Cwa, according to Köppen. Tomato was cultivated in the conventional system in single rows spaced $1.50 \mathrm{~m}$ apart and $0.60 \mathrm{~m}$ between plants.

The experiments were arranged in a completely randomized block design with three replications and five plants per plot. The three plants in the center of the row were used for the statistical analysis. A total of 101 subsamples of tomato from the Vegetable Germplasm Bank of the Federal University of Viçosa (UFV - BGH) belonging to the group salad and two commercial cultivars (Table 1) were evaluated. The subsamples were divided into lots and evaluated in four experiments conducted between August 2003 and July 2007, each experiment with about 30 subsamples and controls.

Twenty-three characteristics related to plant morphology, production and fruit quality were evaluated following the recommendations of the International Plant Genetic Resources Institute (IPGRI, 1996).

The morphological characteristics were measured in leaves and internodes immediately above the third raceme of the second and third plants in the middle section of each plot. The following measurements were taken: leaf length (LL, cm); leaf width (LW, cm); main petiole thickness (MPT, $\mu \mathrm{m})$, internodes length (IL, $\mathrm{cm}$ ) and internode diameter (ID, $\mu \mathrm{m})$. 


\begin{tabular}{|c|c|c|c|c|c|c|c|c|}
\hline \multicolumn{2}{|c|}{ Subsample } & \multirow{2}{*}{$\frac{\text { Origin }}{\text { Pedro Afonso - GO }}$} & \multicolumn{2}{|c|}{ Subsample } & \multirow{2}{*}{$\frac{\text { Origin }}{\text { University of Purdue - USA }}$} & \multicolumn{2}{|c|}{ Subsample } & \multirow{2}{*}{$\frac{\text { Origin }}{\text { University of Purdue - USA }}$} \\
\hline 1 & 4352 & & 36 & 2076 & & 71 & 2177 & \\
\hline 2 & 4546 & Rio Pomba - MG & 37 & 2077 & University of Purdue - USA & 72 & 2178 & University of Purdue - USA \\
\hline 3 & 4547 & Piedade do Rio Grande - MG & 38 & 2078 & University of Purdue - USA & 73 & 2179 & University of Purdue - USA \\
\hline 4 & 4577 & Lavras - MG & 39 & 2083 & University of Purdue - USA & 74 & 2180 & University of Purdue - USA \\
\hline 5 & 4596 & Ilha Murutu - Manaus - AM & 40 & 2088 & University of Purdue - USA & 75 & 2181 & University of Purdue - USA \\
\hline 6 & 4619 & Marajó - Murucurá - AM & 41 & 2089 & University of Purdue - USA & 76 & 2182 & University of Purdue - USA \\
\hline 7 & 4686 & Manaquiri - AM & 42 & 2092 & University of Purdue - USA & 77 & 2183 & University of Purdue - USA \\
\hline 8 & 2003 & University of Purdue - USA & 43 & 2095 & University of Purdue - USA & 78 & 2184 & University of Purdue - USA \\
\hline 9 & 2004 & University of Purdue - USA & 44 & 2096 & University of Purdue - USA & 79 & 2185 & University of Purdue - USA \\
\hline 10 & 2008 & University of Purdue - USA & 45 & 2097 & University of Purdue - USA & 80 & 2186 & University of Purdue - USA \\
\hline 11 & 2011 & University of Purdue - USA & 46 & 2098 & University of Purdue - USA & 81 & 2188 & University of Purdue - USA \\
\hline 12 & 2013 & University of Purdue - USA & 47 & 2100 & University of Purdue - USA & 82 & 2192 & University of Purdue - USA \\
\hline 13 & 2014 & University of Purdue - USA & 48 & 2102 & University of Purdue - USA & 83 & 2194 & University of Purdue - USA \\
\hline 14 & 2016 & University of Purdue - USA & 49 & 2105 & University of Purdue - USA & 84 & 2196 & University of Purdue - USA \\
\hline 15 & 2017 & University of Purdue - USA & 50 & 2109 & University of Purdue - USA & 85 & 2197 & University of Purdue - USA \\
\hline 16 & 2019 & University of Purdue - USA & 51 & 2111 & University of Purdue - USA & 86 & 2222 & University of Purdue - USA \\
\hline 17 & 2020 & University of Purdue - USA & 52 & 2114 & University of Purdue - USA & 87 & 2223 & University of Purdue - USA \\
\hline 18 & 2021 & University of Purdue - USA & 53 & 2115 & University of Purdue - USA & 88 & 2226 & University of Purdue - USA \\
\hline 19 & 2026 & University of Purdue - USA & 54 & 2116 & University of Purdue - USA & 89 & 2227 & University of Purdue - USA \\
\hline 20 & 2027 & University of Purdue - USA & 55 & 2117 & University of Purdue - USA & 90 & 2229 & University of Purdue - USA \\
\hline 21 & 2029 & University of Purdue - USA & 56 & 2118 & University of Purdue - USA & 91 & 2230 & University of Purdue - USA \\
\hline 22 & 2033 & University of Purdue - USA & 57 & 2120 & University of Purdue - USA & 92 & 2233 & University of Purdue - USA \\
\hline 23 & 2035 & University of Purdue - USA & 58 & 2121 & University of Purdue - USA & 93 & 2234 & University of Purdue - USA \\
\hline 24 & 2038 & University of Purdue - USA & 59 & 2124 & University of Purdue - USA & 94 & 2235 & University of Purdue - USA \\
\hline 25 & 2039 Ama & University of Purdue - USA & 60 & 2125 & University of Purdue - USA & 95 & 2236 & University of Purdue - USA \\
\hline 26 & 2039 Verm & University of Purdue - USA & 61 & 2131 & University of Purdue - USA & 96 & 2248 & University of Purdue - USA \\
\hline 27 & 2041 & University of Purdue - USA & 62 & 2132 & University of Purdue - USA & 97 & 2255 & University of Purdue - USA \\
\hline 28 & 2048 & University of Purdue - USA & 63 & 2133 & University of Purdue - USA & 98 & 2269 & University of Purdue - USA \\
\hline 29 & 2054 & University of Purdue - USA & 64 & 2134 & University of Purdue - USA & 99 & $2273 \mathrm{sal}$ & University of Purdue - USA \\
\hline 30 & 2060 & University of Purdue - USA & 65 & 2135 & University of Purdue - USA & 100 & 2274 & University of Purdue - USA \\
\hline 31 & 2064 & University of Purdue - USA & 66 & 2141 & University of Purdue - USA & 101 & 2275 & University of Purdue - USA \\
\hline 32 & 2069 & University of Purdue - USA & 67 & 2149 & University of Purdue - USA & 102 & Fanny & Seminis \\
\hline 33 & 2072 & University of Purdue - USA & 68 & 2150 & University of Purdue - USA & 103 & $\mathrm{St}^{\mathrm{a}}$ Clara & Sakata \\
\hline 34 & 2073 & University of Purdue - USA & 69 & 2151 & University of Purdue - USA & & & \\
\hline 35 & 2075 & University of Purdue - USA & 70 & 2153 & University of Purdue - USA & & & \\
\hline
\end{tabular}


The fruit characteristics were measured in five fruits harvested from the second and third raceme of each of the three plants in the middle section of the plot. The characteristics included: fruit length (FL, cm); fruit width $(\mathrm{FW}, \mathrm{cm})$; pedicel scar width (PSW, $\mu \mathrm{m})$; mesocarp thickness (MT, $\mu \mathrm{m})$; endocarp thickness $(\mathrm{ET}, \mu \mathrm{m})$; central axis width (CAW, $\mu \mathrm{m})$ and locule number (NL, unit).

For fruit quality assessment, the measurements were performed in three fruits per repetition. The following characteristics were measured: total acidity (TA), expressed by the hydrogen potential ( $\mathrm{pH}$ ); total soluble solids (TSS) in ${ }^{\circ}$ Brix, measured with a portable refractometer; total titratable acidity (TTA) expressed as percentage of citric acid and sensory quality (SQ) was obtained by the ratio between TSS and TTA.

Fruit production was assessed by: mean number of marketable fruits per plant $\left(\mathrm{NMF}\right.$, fruit $\left.\mathrm{l}^{-1}\right)$, considering fruits free of pests and/or diseases; mean number of unmarketable fruit per plant (NUF, fruit $\mathrm{pl}^{-1}$ ); mean mass of marketable fruit per plant $\left(\mathrm{MMF}, \mathrm{g} \mathrm{pl}^{-1}\right)$; mean mass of unmarketable fruits per plant (MUF, $\mathrm{g} \mathrm{pl}^{-1}$ ); mean mass of fruit per plant (MF, $\mathrm{g}$ $\left.\mathrm{pl}^{-1}\right)$; mean number of fruit per plant $\left(\mathrm{NF}, \mathrm{g} \mathrm{pl}^{-1}\right)$ and mean total mass of fruit per plant (TMF, $\mathrm{g} \mathrm{pl}^{-1}$ ).

The data obtained for the characteristics evaluated in the subsamples were corrected for the environmental effect by subtracting the overall mean of the controls in the four experiments from the means of the controls of each experiment. To assess the genetic divergence among the subsamples, first, a joint analysis of variance was performed, as suggested by Cruz and Carneiro (2003). The characteristics that showed significant complex interaction (according the concept presented by Cruz \& Castoldi, 1991) between control and experiment were excluded from the analysis of genetic divergence.

The multicollinearity diagnostic test was carried out to identify possible problems in the residual correlation matrix and eliminate some characteristics of moderate to severe multicollinearity.

The relative importance of each characteristic in genetic divergence was determined by the Singh's method (Singh, 1981) and the less important ones were excluded using the methodology proposed by Garcia (1998).

Groups of the subsamples were formed by the Tocher's optimization method, based on the Mahalanobis distance as dissimilarity measure. Analyses were performed using the Genes statistical software (Cruz, 2006).

\section{RESULTS AND DISCUSSION}

The occurrence of significant interaction between the controls and the experiments was assessed for MT, MMF, MMU, TMF, MF, TSS and SQ. This interaction can be represented by two components: one of simple nature and other of complex nature. The complex interaction indicates inconsistency of genotypes for a particular characteristc in different environments, hence, it is advised to be excluded (Cruz and Carneiro, 2003). In this study, only TSS showed complex interaction and was excluded.

Severe multicollinearity (Table 2) was found between NMF and NF, FW and ET, and MMF and TMF. These results indicated the possible exclusion of the variables NMF, ET and MMF because NF, FW and TMF are considered primary components of the total fruit production in the tomato salad group (Rodrigues et al., 2010). The exclusion of these variables is necessary as they may result in problems for the formation of the residual correlation matrix and bias the genetic distance estimates. A weak multicollinearity was found between NF and TMF.

After the exclusion of some variables due to the complex interaction between controls and experiments and others due to severe multicollinearity, we proceeded to the initial clustering of subsamples and analysis of the relative importance using the Singh's method (Singh, 1981). The highest relative importance was found for TMF and the lowest for NUF (Table 3). The analysis of the relative importance does not determine whether or not to exclude variables, it only ranks their importance. However, knowing these values allows us to improve the use of the resources available, and if there is the need for the evaluation of a smaller number of characteristics, we can avoid those that contribute little to the divergence (Suinaga et al., 2003).

Once the relative importance of the characteristics to genetic divergence of the subsamples was calculated, as recommended by Garcia (1998), we excluded the least important, NUF, and performed a new clustering using the Tocher's optimization method to evaluate the effect of the exclusion on group formation (Table 4).

The result of the clustering was identical to that obtained with the characteristic included, which showed that its exclusion did not influence the genetic divergence of the subsamples. The process of exclusion and clustering was repeated with other less important characteristics: ID, IL, TA, LW and MPT, and still no change was

Table 2. Multicollinearity diagnostic test according to Montgomery and Peck (1981) classification

\begin{tabular}{lcc}
\hline Characteristics & Correlation (r) & Multicollinearity* \\
\hline NMF and NF & 0.95 & Severe \\
FW and ET & 0.94 & Severe \\
MMF and TMF & 0.93 & Severe \\
NF and TMF & 0.79 & Weak \\
\hline
\end{tabular}

* Condition number $(\mathrm{CN}) /$ Level of multicollinearity $\mathrm{CN}<100 /$ Weak multicollinearity (not serious problem) $100<\mathrm{CN}<1000 /$ Moderate to strong multicollinearity $>1000 /$ Severe multicollinearity 
observed in the clustering of the subsamples. However, at the eighth cluster analysis, when NF was excluded, the grouping of the subsamples changed and hence no more characteristics were excluded, as it became evident that new exclusions would change the genetic divergence among the genotypes.
In this study, of the 23 characteristics initially considered, only 13 (SQ, TTA, MF, TMF, NF, MUF, LN, CAW, MT, PSW, FW, FL, LL) were effectively required to analyze the genetic divergence among the subsamples, which indicates the possibility of exclusion of characteristics. The sum of the relative importances of TMF, MUF and LL was greater

Table 3. Relative importance of characteristics related to the first and last clustering after exclusion of the least important characteristics according to the Singh's method (Singh, 1981)

\begin{tabular}{|c|c|c|c|}
\hline \multicolumn{2}{|c|}{$1^{\text {st }}$ Clustering } & \multicolumn{2}{|c|}{$7^{\text {th }}$ Clustering } \\
\hline Characteristics & Relative importance $(\%)$ & Characteristics & Relative importance (\%) \\
\hline Sensory quality & 4.12 & Sensory quality & 4.57 \\
\hline Total titrable acidity & 4.54 & Total titrable acidity & 5.08 \\
\hline Total acidity & 1.32 & & \\
\hline Mean fruit mass & 6.54 & Mean fruit mass & 5.87 \\
\hline Total fruit mass & 26.43 & Total fruit mass & 30.42 \\
\hline Total fruit number & 1.76 & Total fruit number & 2.23 \\
\hline Unmarketed fruit mass & 13.01 & Unmarketed fruit mass & 12.21 \\
\hline Unmarketed fruit number & 0.75 & & \\
\hline Locule number & 4.76 & Locule number & 5.40 \\
\hline Central axis width & 5.85 & Central axis width & 6.28 \\
\hline Mesocarp thickness & 2.75 & Mesocarp thickness & 2.88 \\
\hline Pedicel scar width & 3.54 & Pedicel scar width & 3.70 \\
\hline Fruit width & 4.80 & Fruit width & 5.36 \\
\hline Fruit length & 11.78 & Fruit length & 13.03 \\
\hline Internode diameter & 1.03 & & \\
\hline Internode length & 1.05 & & \\
\hline Main petiole thickness & 1.65 & & \\
\hline Leaf width & 1.45 & & \\
\hline Leaf length & 2.77 & Leaf length & 2.91 \\
\hline
\end{tabular}

Table 4. Clustering by the Tocher's optimization method of 101 subsamples and two commercial cultivars of tomato evaluated for 23 characteristics with subsequent exclusion of those with the least relative importance to the genetic divergence of the subsamples

\begin{tabular}{|c|c|c|}
\hline Clustering & Groups & Subsamples \\
\hline \multirow[t]{3}{*}{$1^{\text {st }}$} & I & $\begin{array}{l}25 ; 26 ; 18 ; 9 ; 24 ; 23 ; 14 ; 20 ; 82 ; 77 ; 36 ; 4 ; 11 ; 31 ; 85 ; 32 ; 81 ; 76 ; 71 ; 75 ; 79 ; 33 ; 67 ; 70 ; 10 ; 72 ; 86 \\
27 ; 45 ; 80 ; 66 ; 29 ; 3 ; 13 ; 42 ; 41 ; 34 ; 83 ; 69 ; 2 ; 58 ; 49 ; 57 ; 12 ; 47 ; 48 ; 28 ; 59 ; 68 ; 84 ; 52 ; 73 ; 63 ; 21 \\
35 ; 51 ; 53 ; 39 ; 56 ; 60 ; 64 ; 65 ; 15 ; 50 ; 22 ; 61 ; 102 ; 46 ; 37 ; 103 ; 19 ; 8 ; 38 ; 44 ; 16 ; 54 ; 5 ; 1 ; 91 ; 78 ; \\
62 ; 74 ; 40 ; 30 ; 6 ; 87 ; 7 ; 43 ; 98 ; 17 ; 55 ; 93 ; 92 ; 95\end{array}$ \\
\hline & II & $88 ; 94 ; 101 ; 97 ; 90 ; 96 ; 100 ; 89$ \\
\hline & III & 99 \\
\hline \multirow[t]{3}{*}{$7^{\text {th }}$} & I & $\begin{array}{l}25 ; 26 ; 18 ; 9 ; 24 ; 23 ; 14 ; 20 ; 82 ; 77 ; 36 ; 4 ; 11 ; 31 ; 85 ; 32 ; 81 ; 76 ; 71 ; 75 ; 79 ; 33 ; 67 ; 70 ; 10 ; 72 ; 86 \\
27 ; 45 ; 80 ; 66 ; 29 ; 3 ; 13 ; 42 ; 41 ; 34 ; 83 ; 69 ; 2 ; 58 ; 49 ; 57 ; 12 ; 47 ; 48 ; 28 ; 59 ; 68 ; 84 ; 52 ; 73 ; 63 ; \\
21 ; 35 ; 51 ; 53 ; 39 ; 56 ; 60 ; 64 ; 65 ; 15 ; 50 ; 22 ; 61 ; 102 ; 46 ; 37 ; 103 ; 19 ; 8 ; 38 ; 44 ; 16 ; 54 ; 5 ; 1 ; 91 \\
78 ; 62 ; 74 ; 40 ; 30 ; 6 ; 87 ; 7 ; 43 ; 98 ; 17 ; 55 ; 93 ; 92 ; 95\end{array}$ \\
\hline & II & $88 ; 94 ; 101 ; 97 ; 90 ; 96 ; 100 ; 89$ \\
\hline & III & 99 \\
\hline \multirow[t]{3}{*}{$8^{\text {th }}$} & I & $\begin{array}{l}25 ; 26 ; 18 ; 9 ; 24 ; 23 ; 14 ; 20 ; 82 ; 77 ; 36 ; 4 ; 11 ; 31 ; 85 ; 32 ; 81 ; 76 ; 71 ; 75 ; 79 ; 33 ; 67 ; 70 ; 10 ; 72 ; 86 \\
27 ; 45 ; 80 ; 66 ; 29 ; 3 ; 13 ; 42 ; 41 ; 34 ; 83 ; 69 ; 2 ; 58 ; 49 ; 57 ; 12 ; 47 ; 48 ; 28 ; 59 ; 68 ; 84 ; 52 ; 73 ; 63 ; 21 \\
35 ; 51 ; 53 ; 39 ; 56 ; 60 ; 64 ; 65 ; 15 ; 50 ; 22 ; 61 ; 102 ; 46 ; 37 ; 103 ; 19 ; 8 ; 38 ; 94 ; 90 ; 96 ; 44 ; 16 ; 54 ; 5 ; \\
1 ; 91 ; 78 ; 62 ; 74 ; 40 ; 30 ; 6 ; 87 ; 7 ; 43 ; 98 ; 17 ; 55 ; 93 ; 92 ; 95\end{array}$ \\
\hline & II & $97 ; 101 ; 88 ; 100 ; 89$ \\
\hline & III & 99 \\
\hline
\end{tabular}


than 55\%, showing that they account for most of the genetic divergence between the subsamples. The Tocher's method (Table 5) clustered the subsamples into three groups: Group I, the largest group, with 92 subsamples having in general similar characteristics to the two controls, which were also clustered in this group. Groups II and III had eight and one subsamples respectively. The results show, therefore, that although the subsamples belong to the same commercial Salad group, they have genetic variability with possible gains from breeding.

Because Group I included most of the subsamples analyzed $(91 \%)$ and the Tocher's method allows the estimation of intra and inter-group distances, the subgrouping procedure was carried out for this group. Six subgroups were formed with $65,10,5,3,3$ and 2 subsamples, while 6 subsamples were not grouped with any other (Table 5).

The clustering of the subsamples (Table 5) was not associated with their origin (Table 1). For instance, the subsample 40 (group I) and subsample 99 (group III) from Purdue University were clustered into different groups. On the other hand, subsamples from different geographical regions of Brazil, such as the subsamples 1, 2, 3 and 4 were clustered in the same group.

Table 5. Groups and subgroups formed from 101 tomato subsamples from the VGB-UFV and two commercial cultivars by the Tocher's optimization method based on the evaluation of 13 charateristics

\begin{tabular}{ccl}
\hline Groups & Subgroups & \multicolumn{1}{c}{ Subsamples } \\
\hline & & $53 ; 64 ; 15 ; 58 ; 31 ; 14 ; 39 ; 35 ; 23 ; 11 ; 27 ; 9 ; 21 ; 24 ; 57 ; 33 ; 85 ; 68 ; 77 ; 36 ; 41 ; 71 ; 28 ; 82 ; 10 ; 13 ; 32 ;$ \\
I & 4 & $4 ; 75 ; 67 ; 81 ; 76 ; 83 ; 3 ; 69 ; 29 ; 72 ; 66 ; 79 ; 19 ; 45 ; 20 ; 86 ; 70 ; 42 ; 34 ; 49 ; 80 ; 2 ; 47 ; 48 ; 59 ; 56 ; 84 ;$ \\
& 2 & $25 ; 26 ; 38 ; 78 ; 74$ \\
& 3 & $5 ; 6 ; 1 ; 54 ; 61 ; 43 ; 16 ; 17 ; 55 ; 62$ \\
& 4 & $93 ; 98 ; 92$ \\
& 5 & $44 ; 103 ; 46$ \\
& 6 & $8 ; 30$ \\
& 7 & 102 \\
& 8 & 7 \\
& 9 & 91 \\
& 10 & 40 \\
& 11 & 87 \\
III & 12 & 95 \\
& & $88 ; 94 ; 101 ; 97 ; 90 ; 96 ; 100 ; 89$ \\
\hline
\end{tabular}

\section{CONCLUSIONS}

The tomato subsamples of the Salad group from the Vegetable Germplasm Bank - UFV are genetically divergent and gains can be obtained by selection.

Characteristics can be excluded without changing the original genetic divergence.

The characteristics mean total mass of fruits per plant, mean mass of unmarketable fruits per plant and fruit length are the highest contributors to genetic divergence of the tomato subsamples of the Salad group from the Vegetable Germplasm Bank - UFV .

The subsample 'BGH-2273 sal' is the most divergent among all tomato subsamples of the Salad group from the Vegetable Germplasm Bank - UFV.

Over $90 \%$ of the subsamples evaluated were clustered into the same group of the commercial controls.

\section{REFERENCES}

Caliman FRB, Silva DJH, Fontes PC, Stringheta PC, Moreira GR \& Cardoso AA (2005) Avaliação de genótipos de tomateiro cultivados em ambiente protegido e em campo nas condições edafoclimáticas de Viçosa. Horticultura Brasileira, 23:255-259.

Castro JPA, Nick C, Milagres CC, Mattedi AP, Marim BG \& Silva DJH (2010) Genetic diversity among tomato's subsamples for prebreeding. Crop Breeding and Applied Biotechnology, 10:74-82.

Cruz CD \& Castoldi F (1991) Decomposição da interação genótipo $\mathrm{x}$ ambiente em partes simples e complexas. Revista Ceres, 38:422-430.

Cruz CD \& Carneiro PCS (2003) Modelos biométricos aplicados melhoramento genético. Viçosa, Editora UFV. 585p.

Cruz CD (2006) Programa Genes: Biometria. Viçosa, Editora UFV. 382 p.

Fiorini CVA, Silva DJH, Mizubuti ESG, Barros JS, Silva LJ, Milagres C \& Zaparoli MR (2010) Caracterização de linhagens de tomateiro originadas de cruzamento interespecífico quanto à resistência à requeima. Hoticultura Brasileira, 28:197-202. 
Garcia SLR (1998) Importância de características de crescimento, de qualidade da madeira e da polpa na diversidade genética de clones de eucalipto. Dissertação de Mestrado. Universidade Federal de Viçosa, Viçosa. 103p.

Guimarães MA, Silva DJH, Fontes PCR, Caliman FRB, Loos RA \& Stringheta PC (2007) Produção e sabor dos frutos de tomateiro submetidos a poda apical e de cachos florais. Horticultura Brasileira, 25:259-263.

Guimarães MA, Silva DJH, Fontes PCR \& Mattedi AP (2008) Produtividade e sabor dos frutos de tomate do grupo salada em função de podas. Bioscience Journal, 24:32-38.

IPGRI (1996) Descriptors for tomato (Lycopersicon spp). Roma, International Plant Genetic Resources Institute. 56p.

Haussmann BIG, Parzies HK, Presterl T, Susic Z \& Miedaner T (2004) Plant genetic resources in crop improvement. Plant genetic resources, 2:03-21.

Marim BG, Silva DJH, Guimarães MA \& Belfort G (2005) Sistemas de tutoramento e condução do tomateiro visando produção de frutos para consumo in natura. Horticultura Brasileira, 23:951-955.

Montgomery DC \& Peck EA (1981) Introduction to linear regression analysis. New York, John Wiley. 504p.
Oliveira FA, Silva DJH, Leite GLD, Jham GN \& Picanço M (2009) Resistance of 57 greenhouse-grown accessions of Lycopersicon esculentum and three cultivars to Tuta absoluta (Meyrick) (Lepidoptera: Gelechiidae). Scientia Horticulturae, 119:182187.

Rodrigues GB, Marim BG, Silva DJH, Mattedi AP \& Almeida VS (2010) Análise de trilha de componentes primários e secundários em tomateiro do grupo Salada. Pesquisa Agropecuária Brasileira, 45:155-162.

Singh D (1981) The relative importance of characters affecting genetic divergence. The Indian Journal of Genetic and Plant Breeding, 41:237-245.

Suinaga FA, Casali VW, Silva DJH \& Picanço M (2003) Dissimilaridade genética de fontes de resistência de Lycopersicon spp. a Tuta absoluta (MEYRICK, 1917) (LEPIDOPTERA: GELECHIDAE). Revista Brasileira de Agrociência, 9:371-376.

Upadhyaya HD, Reddy LJ, Gowda CLL, Reddy KN \& Singh S (2006) Development of a mini core subset for enhanced and diversified utilization of pigeonpea germplasm resources. Crop Science, 46:2127-2132. 